Arkadiusz Mirosław Czaja, Urząd obrońcy węzła małżeńskiego po II wojnie światowej. Aspekty historyczno-prawne, [w:] Struktura i działalność Sądu Diecezjalnego w Tarnowie w latach 1945-1983, red. Robert Kantor, Kraków 2019, s. 91-103.

DOI: http://dx.doi.org/10.15633/9788374387309.06

Arkadiusz MirosŁaw Czaja OFM

Uniwersytet im. Adama Mickiewicza w Poznaniu

\title{
Urząd obrońcy węzła małżeńskiego po II wojnie światowej. Aspekty historyczno-prawne
}

Rozważając problematykę związaną z urzędem obrońcy węzła małżeńskiego w procesie o stwierdzenie nieważności małżeństwa, należy spojrzeć na to zagadnienie przez pryzmat historii. Pozwoli to lepiej zrozumieć znaczenie i specyfikę tego szczególnego urzędu w sądownictwie kościelnym. W opracowaniu temat zawężony zostanie do tematu obrońcy węzła w sprawach o stwierdzenie nieważności małżeństwa.

\section{Przyczyna ustanowienia urzędu obrońcy węzła małżeńskiego}

Zarówno brak profesjonalnego przygotowania osób do pełnienia urzędów w kościelnym sądownictwie, jak i prądy ideowe promujące indywidualizm, które spowodowały zanik zasad moralnych w XVIII wieku w sporej części społeczeństwa, przełożyły się na dużą liczbę rozbitych małżeństw. Wszystko to spowodowało potrzebę ochrony małżeństwa jako instytucji dobra publicznego Kościoła katolickiego. Ówczesne prawodawstwo kościelne w niewystarczający sposób zabezpieczało prawnie instytucję małżeństwa przed nadużyciami w kwestii jego nierozerwalności. Dlatego papież Benedykt xıv, zatroskany o trwałość i świętość małżeństw, wydał konstytucję apostolską Dei miseratione, ogłoszoną w 1741 roku, w której pojawił się obowiązek ustanowienia urzędu obrońcy węzła (defensor vinculi) w każdym trybunale 
diecezjalnym ${ }^{1}$. Powyższy nakaz prawny miał na celu położenie kresu nadużyciom, jakie zaistniały w procesach o stwierdzenie nieważności małżeństwa ${ }^{2}$. Zaobserwowane ówcześnie negatywne postawy dotyczyły przede wszystkim braku roztropności wśród sędziów kościelnych przy orzekaniu w sprawach dotyczących małżeństwa. Ustanowienie przez papieża urzędu obrońcy węzła miało w zamierzeniu stać na straży integralności procesu i bronić ważności, świętości oraz nierozerwalności małżeństwa ${ }^{3}$. Kanonista biskupski określał obrońcę węzła małżeńskiego jako „rzecznika świętości małżeństwa”; sformułowanie to w pełni oddaje istotę tego urzędu. Małżeństwo jest darem Bożym, dlatego podkreślenie jego świętości jest jak najbardziej trafne, a obrońca węzła winien stać na jej straży.

Nadużycia względem trwałości małżeństwa w XVIII wieku miały miejsce również w kościelnej praktyce sądowej w Polsce 5 . Sposób i szybkość wprowadzania w życie przepisów o obrońcy węzła w sądownictwie kościelnym w następnych latach w Królestwie Polskim pozostawiały wiele do życzenia, dlatego papież Benedykt xıv był zmuszony skierować w 1743 roku pismo okólne Nimiam licentiam do polskich biskupów, w którym przypominał o obowiązujących przepisach prawa kanonicznego w sprawach małżeńskich ${ }^{6}$.

Z analizy materiału źródłowego sądownictwa kościelnego w Królestwie Polskim w XVıı wieku wynika, że były Kościoły partykularne, które

1 Por. Benedictus xIv, Dei miseratione (1741), w: Codicis Iuris Canonici Fontes, cura P. Gasparri, Vol. 1, N. 318, Romae 1926, s. 695.

2 Por. M. Greszata, Iudicium cum principiis. Kodeksowa weryfikacja wybranych zasad procesowych w kanonicznych sprawach o nieważność matżeństwa, Lublin 2008, s. 230.

3 Benedictus xIV, Dei miseratione (1741), dz. cyt., s. 697, $\$$ 6: „[...] cumque oportebit [...] voce et scriptis matrimonii validitatem tueri, eaque omnia deducere, quae ad matrimonium sustinendum necessaria censebit"; por. T. Pawluk, Prawo kanoniczne wedtug Kodeksu Jana Pawła II, t. 4, Doczesne dobra Kościoła. Sankcje w Kościele. Procesy, Olsztyn 1990, s. 200.

4 S. Biskupski, Obrońca węzła w kanonicznym procesie małżeńskim, Łódź 1937, s. 121.

5 Por. A. Wójcik, Rola aktywności obrońcy węzła małżeńskiego w procesie o stwierdzenie nieważności małżenstwa, w: Urzędy sądowe - władza i służba. Materiały z Ogólnopolskiego Spotkania Pracowników Sądownictwa Kościelnego w Gródku nad Dunajcem w dniach 11-12 października 2004 roku, red. T. Rozkrut, Tarnów 2005, s. 90.

6 Por. Benedictus xiv, Nimiam licentiam (1743), w: Codicis Iuris Canonici Fontes, dz. cyt., s. 791, $\$ 4$. 
od samego początku wprowadziły w życie przepisy konstytucji apostolskiej w swoich sądach. Do nich zaliczały się diecezje płocka, włocławska i wileńska. W 1750 roku urząd obrońcy węzła małżeńskiego został wprowadzony w diecezji warszawskiej, a w 1752 - w żmudzkiej. Natomiast $\mathrm{w}$ archidiecezji krakowskiej pierwsza wzmianka w aktach procesowych o ustanowieniu obrońcy węzła małżeńskiego pojawiła się w 1747 roku. Z kolei biskup diecezji chełmskiej i lubelskiej w 1792 roku nakazywał, by w sądzeniu spraw o ważność małżeństw dokładnie zachowywać przepisy konstytucji apostolskiej Benedykta XIV ${ }^{7}$.

Przepisy prawa kanonicznego odnośnie do instytucji obrońcy węzła nie były od razu w pełni przestrzegane przez wszystkie diecezje. $Z$ tych ogólnych przykładów widać, że rozumienie znaczenia urzędu obrońcy węzła w sprawach małżeńskich było różne. Nawet gdy obrońca węzła był już ustanowiony, nie występował we wszystkich sprawach o stwierdzenie nieważności małżeństwa. Kanonista biskupski uważał, że przepisów dotyczących obrońcy węzła małżeńskiego przestrzegano w Polsce formalnie, ale wykonanie zarządzeń w większości wypadków było dalekie od ideału ${ }^{8}$.

\section{Charakter prawny instytucji obrońcy węzła małżeńskiego}

Obrońca węzła małżeńskiego od samego początku jego ustanowienia przez papieża Benedykta XIV - jako instytucja sądownictwa kościelnego - był zobowiązany starać się, aby zaskarżoną ważność małżeństwa godziwymi sposobami i zgodnie z prawem kanonicznym utrzymać w mocy. Konstytucja Dei miseratione nałożyła na wszystkich ordynariuszów Kościołów partykularnych obowiązek zamianowania obrońcy węzła, urzędowej osoby stojącej na straży dobra publicznego w zakresie nierozerwalności małżeństwa ${ }^{9}$, ponieważ sprawy go dotyczące zawsze były objęte przez Kościół katolicki szczególną opieką i troską.

W procesach o stwierdzenie nieważności małżeństwa, jakie toczyły się na przestrzeni lat w Sądzie Diecezjalnym w Tarnowie, zawsze występował obrońca węzła małżeńskiego. Jego znaczenie dla całego procesu zawsze było nie do przecenienia. Urząd ten stanowił ważną instytucję

\footnotetext{
7 Por. S. Biskupski, Obrońca węzła..., dz. cyt., s. 106-107.

8 Por. S. Biskupski, Obrońca węzła..., dz. cyt., s. 104-107.

9 Por. S. Biskupski, Obrońca węzła..., dz. cyt., s. 111.
} 
w procesach kościelnych dotyczących spraw małżeńskich. Działalność procesowa Sądu Diecezjalnego w Tarnowie jest udokumentowana od 1933 roku. A zatem do 1983 roku w księgach procesowych można znaleźć informacje na temat 1550 procesów ${ }^{10}$.

Sam urząd obrońcy węzła był ustanawiany, tak w Sądzie Diecezjalnym w Tarnowie, jak i w innych diecezjach, w celu ochrony dobra publicznego w 2 kategoriach. Pierwsza $\mathrm{z}$ nich to sprawy, które dotyczą nieważności przyjętych przez katolika święceń. Natomiast drugą kategorię stanowią sprawy o stwierdzenie nieważności małżeństwa i rozwiązanie węzła małżeńskiego ${ }^{11}$. Powołany do życia urząd obrońcy węzła małżeńskiego został wyposażony w odpowiednie narzędzia ochrony prawnej. Miało to wyeliminować istniejące nadużycia w kościelnych procesach oraz naprawić postępujące ówcześnie - w XVIII wieku - osłabienie życia moralnego i religijnego wśród katolików ${ }^{12}$.

Prawodawstwo Kościoła od xviıI wieku nakazywało, by dla wszystkich spraw sądowych dotyczących stwierdzenia nieważności małżeństwa, w każdym sądzie kościelnym, ustanowić na stałe obrońcę węzła małżeńskiego, dlatego jego powołanie było obowiązkowe. Do momentu ustanowienia obrońcy węzła procedura sądowa w sprawach małżeńskich nie znała odrębnego urzędu, który byłby niezależny od sędziego, a powołany w celu obrony dobra publicznego, jakim jest małżeństwo. W imieniu Kościoła i w obronie praw oraz dobra publicznego występował jedynie wówczas sam sędzia. Z ówczesnego doświadczenia sądowego wynikało, że nie dawało to dostatecznej gwarancji skutecznej obrony węzła małżeńskiego. A zatem troska o małżeństwo spowodowała powołanie nowego

${ }^{10}$ Por. G. Salamon, Ogólne zestawienie procesów w Sądzie Diecezjalnym, w: Struktura i działalność Sądu Diecezjalnego w Tarnowie w latach 1983-2015, red. R. Kantor, Kraków 2016, s. 155 .

${ }^{11}$ Codex Iuris Canonici, Pii X P.M. iussu digestus, Benedicti P. xv auctoritate promulgatus, „Acta Apostolicae Sedis” [dalej: AAs] 9 (1917) pars II, s. 1-521 [dalej: CICB], can. 1586: „Constituatur in dioecesi [...] defensor vinculi; ille pro causis, tum contentiosis in quibus bonum publicum, Ordinarii iudicio, in discrimen vocari potest, tum criminalibus; iste pro causis, in quibus agitur de vinculo sacrae ordinationis aut matrimonii”; por. can. $1588 § 2$ : "[...] defensor constitui possunt tum ad universitatem causarum tum pro singulis causis".

${ }_{12}$ Por. W. Wenz, P. Wróblewski, Urząd obrońcy węzła i procesowe decyzje sędziego na etapie wyrokowania. Zagadnienia wybrane z procesu o nieważność matżeństwa, Wrocław 2007, s. 24. 
urzędu, którego zadaniem było czuwanie w imieniu Kościoła nad obroną praw należnych społeczności religijnej w sprawach małżeńskich.

Obrońca węzła - tak w przeszłości, jak również i w dzisiejszym prawodawstwie kanonicznym - jest wyznaczany w chwili powołania składu sędziowskiego przez wikariusza sądowego, natomiast formalnie rozpoczyna działanie od momentu powiadomienia go o przyjęciu skargi powodowej. Jego zadaniem jest przedstawienie tego wszystkiego, co w sposób logiczny i godziwy może wskazywać na ważność i trwałość węzła małżeńskiego ${ }^{13}$. Sędzia był zawsze zobowiązany powiadomić obrońcę węzła o sprawie przyjętej do rozpatrywania, a także udzielić mu prawa głosu, jak i przekazać akta sprawy do wglądu. Jako przedstawiciel Kościoła zawsze był zobowiązany $z$ urzędu do udziału w procesie o stwierdzenie nieważności małżeństwa, aby wszelkimi przewidzianymi przez prawo kanoniczne sposobami bronić ważności małżeństwa ${ }^{14}$. Jednakże nigdy nie reprezentował on ani siebie, ani biskupa diecezjalnego, ale Kościół jako inicjatora postępowania sądowego. $\mathrm{Z}$ mocy prawa podlega jedynie wikariuszowi sądowemu, a w konkretnym procesie - przewodniczącemu trybunału.

Na przestrzeni wieków w literaturze kanonistycznej spotyka się różne stanowiska odnośnie do roli instytucji obrońcy węzła małżeńskiego ${ }^{15}$. Część kanonistów uważa, że należy go traktować jako stronę pozwaną $\mathrm{w}$ procesie o stwierdzenie nieważności małżeństwa. Jednak trafniejsza wydaje się teza, że stroną pozwaną jest władza kościelna, która zawsze jest zainteresowana uzyskaniem przez sąd potwierdzenia ważności lub nieważności zaskarżonego małżeństwa, przy poszanowaniu prawdy obiektywnej. Dlatego obrońca węzła małżeńskiego występuje w procesie jako reprezentant Kościoła katolickiego ${ }^{16}$. Spotyka się też stanowisko,

${ }^{13}$ Codex Iuris Canonici auctoritate Ioannis Pauli PP. II promulgatus, 25.01.1983, AAS 75 (1983) pars II, s. 1-317; tekst łacińsko-polski: Kodeks prawa kanonicznego, przekład zatwierdzony przez Konferencję Episkopatu Polski, Poznań 1984 [dalej: cic], can. 1432: „[...] in dioecesi defensor vinculi, qui officio tenetur proponendi et exponendi omnia quae rationabiliter adduci possint adversus nullitatem vel solutionem"; por. M. Sitarz, Obrońca węzła, w: Słownik prawa kanonicznego, red. M. Sitarz, Warszawa 2004, kol. 119.

${ }^{14}$ Por. S. Biskupski, Obrońca węzła..., dz. cyt., s. 100-101.

${ }_{15}$ Por. J. Krukowski, Artykuł 3. Promotor sprawiedliwości, obrońca węzła i notariusz, w: Komentarz do Kodeksu Prawa Kanonicznego, t. 5, ks. viI, Procesy, red. J. Krukowski, Poznań 2007, s. 49.

${ }_{16}$ Por. Z. Grocholewski, Parte convenuta nelle cause di nullita di matrimonio, w: R. M. Pizzorni, G. Di Mattia, Vitam impendere Magisterio. Profilo intellettuale e scritti 
że obrońca węzła nie jest stroną w toczącej się sprawie, lecz trzecią osobą interweniującą w procesie, zwłaszcza jeśli opinie 2 stron co do ważności czy nieważności małżeństwa są sprzeczne ze sobą. Kanonista Franciszek Bączkowicz stwierdzał, przywołując przepisy Kodeksu prawa kanonicznego z 1917 roku, że gdy oboje małżonkowie i ewentualnie promotor sprawiedliwości dążą do ogłoszenia nieważności małżeństwa, obrońca węzła jest wtedy jakby stroną procesową. Jeśli jedna strona jest za nieważnością małżeństwa, a druga za ważnością, wtedy obrońca jest „interwenientem” ${ }^{17}$. Spotyka się też w literaturze kanonistycznej stanowisko, że jest stroną sui generis bądź reprezentantem strony ${ }^{18}$. Jednakże na podstawie obecnie obowiązującego prawa kanonicznego nie można go zakwalifikować jako strony ${ }^{19}$.

\section{Wymagania prawne stawiane kandydatom na urząd obrońcy węzła małżeńskiego}

W Kościele katolickim są urzędy o szczególnym znaczeniu, które zawsze łączyły się z większą odpowiedzialnością, co również było związane z obowiązkami nakładanymi na sprawujące je osoby. Wśród nich jest też urząd obrońcy węzła małżeńskiego. Dlatego nie dziwi to, że od samego początku prawo kanoniczne wymagało od osób ubiegających się o to stanowisko bardzo wysokich kwalifikacji, które powinny być gwarancją solidności w pełnieniu powierzonych zadań. Obrońca węzła w Sądzie Diecezjalnym w Tarnowie reprezentuje wspólnotę Kościoła, broniąc nierozerwalności i sakramentalności małżeństwa. Dlatego - tak na przestrzeni dawnych lat, jak i dziś - najważniejszym jego zadaniem pozostaje ochrona dobra publicznego, które zakłada, że każde małżeństwo jest ważne, jeśli zostało zawarte zgodnie z przepisami prawa kanonicznego. Obrońca węzła małżeńskiego nie mógł zadowolić się jedynie ogólną

in onore dei professori Reginaldo M. Pizzorni, O.P., e Giuseppe di Mattia, O.F.M. Conv., Roma 1993, s. 41-55.

${ }_{17}$ Por. F. Bączkowicz, Prawo kanoniczne. Podręcznik dla duchowieństwa, t. 3, wyd. 3, Opole 1958, s. 196.

${ }_{18}$ Por. G. Leszczyński, Rola obrońcy węzła małżeńskiego w procesie o stwierdzenie nieważności małżeństwa, „Prawo Kanoniczne. Kwartalnik prawno-historyczny” 49 (2006) nr 3-4, s. 52.

${ }_{19}$ Por. G. Leszczyński, Rola obrońcy..., dz. cyt., s. 52. 
znajomością akt sprawy zaskarżonego małżeństwa, lecz był zobligowany do podjęcia analizy dowodów, by wypowiedzieć się jednoznacznie co do zgromadzonego materiału dowodowego. Sam Święty Jan Paweł II w przemówieniu do członków Trybunału Roty Rzymskiej przypominał, że rola i zadania obrońcy węzła małżeńskiego są bardzo ważne i niezastąpione w sądownictwie kościelnym ${ }^{20}$.

Kodeks prawa kanonicznego z 1917 roku wprowadził wymóg, aby kandydat na obrońcę węzła posiadał święcenia kapłańskie. Po raz pierwszy mowa o tym w dokumencie Lex propria sacrae Romanae Rotae et Signaturae Apostolicae ${ }^{21}$. Kanonista biskupski tłumaczy nakaz posiadania święceń kapłańskich tym, że kapłan „więcej ma zmysłu i ducha kościelnego" niż osoba świecka czy też osoba duchowna o niższych święceniach ${ }^{22}$. Natomiast Kodeks prawa kanonicznego z 1983 roku znacznie rozszerzył kryteria dotyczące wyboru osoby na urząd obrońcy węzła względem przepisów zawartych w kodeksie z 1917 roku. W obecnym prawie kanonicznym nie ma już takiego nakazu, że musi być to osoba posiadająca święcenia kapłańskie. A zatem nowością jest to, że urząd ten może pełnić nawet osoba świecka, i to niezależnie od $\mathrm{płci}^{23}$. Już konstytucja apostolska Dei miseratione dopuszczała w nadzwyczajnych sytuacjach możliwość pełnienia urzędu obrońcy węzła przez osoby świeckie.

Prawodawca kościelny zawsze wymaga od kandydata na urząd obrońcy węzła małżeńskiego odpowiednich przymiotów, jakimi są: dobre imię, nieposzlakowana opinia, nienaganna zarówno w przeszłości, jak i w momencie przyjmowania urzędu, a także mądrość oraz gorliwość w dążeniu do sprawiedliwości i prawdy. Dobre imię nie mogło być w niczym naruszone ani umniejszone w opinii ludzi poważanych, religijnych

${ }^{20}$ Por. Ioannes Paulus II, Ad Romanae Rotae Auditores simul cum officialibus et advocatis coram admissos, anno forensi ineunte (die 25.01.1988), AAs 80 (1988) N. 3, s. 1178-1185.

${ }^{21}$ Lex propria sacrae Romanae Rotae et Signaturae Apostolicae, "Acta Sanctae Sedis” 41 (1908), s. 441, can. $4 \$ 2:$ „Hisacerdotes esse debent [...]”.

${ }_{22}$ S. Biskupski, Obrońca węzła..., dz. cyt., s. 119: „[...] że kapłan - z racji swego powołania - więcej ma zmysłu i ducha kościelnego, to też żarliwiej i z większą dla sprawy obrony sakramentu korzyścią może swój urząd pełnić, niż osoby świeckie, a choćby i duchowe, ale niższych święceń". Zachowano pisownię oryginalną cytatu.

${ }^{23}$ CIC, can. 1435: „Episcopi est [...] vinculi defensorem nominare, qui sint clerici vel laici [...]"; por. R. Biernat, Obrońca węzła małżeńskiego w procesach I Instancji Sądu diecezjalnego w Tarnowie, w: Struktura i działalność Sądu Diecezjalnego w Tarnowie w latach 1983-2015, dz. cyt., s. 56. 
i uczciwych. Tam, gdzie dokonuje się wymiar sprawiedliwości, osoby biorące czynny udział przy rozpatrywaniu i rozstrzyganiu procesu muszą być poza wszelkimi podejrzeniami o nieuczciwość i niekompetentność; także w obecnym prawie kanonicznym wymaga się od kandydata na urząd obrońcy węzła małżeńskiego posiadania tych wszystkich powyższych przymiotów ${ }^{24}$. Jeśli biskup diecezjalny miałby wątpliwości, czy osoba mająca pełnić ten urząd je posiada, nie powinien jej mianować, dopóki nie upewni się, że spełnia wszystkie warunki wymagane w prawie kościelnym ${ }^{25}$.

Od obrońcy węzła małżeńskiego wymaga się całościowej oceny sprawy. Ocena spraw sądowych wymaga namysłu, roztropności i specjalnego wyczucia, które nazywa się zmysłem sprawiedliwości ${ }^{26}$. Obrońca węzła, by dobrze wypełniał swoją posługę, nie może ograniczać się do pobieżnego przeczytania akt sprawy procesowej. Powinien być szczególnie wyczulony na sytuacje, gdy prawo kanoniczne jest naruszane, ponieważ jego interwencja skierowana jest ku szukaniu prawdy o zaskarżonym małżeństwie. Prawo kanoniczne wymagało również od obrońcy węzła małżeńskiego odpowiedniego stopnia naukowego, a także dużej wiedzy teologicznej i prawniczej. Papież Benedykt xıv i jego następcy zdawali sobie sprawę, że tylko dobrze przygotowana osoba będzie mogła spełniać zadanie należytej ochrony nierozerwalności małżeństwa. Jeśli chodzi o stopień naukowy, gwarancją doświadczenia kandydata było uzyskanie stopnia akademickiego. Z czasem wymóg kwalifikacji akademickich uległ zmianom, ponieważ Kodeks prawa kanonicznego z 1917 roku wymagał stopnia naukowego doktora prawa kanonicznego lub biegłości w prawie kanonicznym ${ }^{27}$. Z kolei Kodeks prawa kanonicznego z 1983 roku nadal utrzymuje $\mathrm{w}$ mocy wymóg posiadania doktoratu $\mathrm{z}$ prawa

${ }^{24}$ CIC, can. 1435; por. DC, art. $56 \$ 4$.

${ }_{25}$ Por. R. Biernat, Obrońca węzła małżeńskiego w procesach I Instancji..., dz. cyt., s. 56.

${ }^{26}$ Por. S. Biskupski, Obrońca węzła..., dz. cyt., s. 121.

${ }^{27} \mathrm{CICB}$, can. $1589 \$ 1$ : „Ordinarii est promotorem iustitiae et vinculi defensorem eligere, qui sint sacerdotes integrae famae, in iure canonico doctores vel ceteroqui periti, ac prudentiae et iustitiae zelo probati”; can. $1589 \$ 2$ : „In tribunali religiosorum promotor iustitiae sit praeterea eiusdem religionis alumnus"; por. M. Stasiak, Dylemat defensora: chronić instytucję małżeństwa czy dobro osoby?, w: Divina et humana. Księga jubileuszowa w 65. rocznicę urodzin księdza profesora Henryka Misztala, red. A. Dębiński, W. Bar, P. Stanisz, Lublin 2001, s. 716. 
kanonicznego, ale jednocześnie dopuszcza do pełnienia urzędu obrońcy węzła małżeńskiego osoby $\mathrm{z}$ wykształceniem licencjackim $\mathrm{z}$ dziedziny prawa kanonicznego ${ }^{28}$.

Na przestrzeni historii prawodawstwo kościelne stawiało obrońcy węzła wymagania, które dotyczyły także odpowiedniego wieku. Kodeks prawa kanonicznego z 1917 roku nie wspomina wprost o tym obowiązku, lecz ustawy prawa kanonicznego zobowiązywały biskupa do uwzględnienia tego aspektu ${ }^{29}$. Przyjmuje się bowiem w powszechnej ocenie, że roztropność nabywa się przeważnie z wiekiem. Prawodawca, stawiając pośrednio takie kryterium kandydatowi na urząd obrońcy węzła, podkreśla ważność oraz odpowiedzialny charakter tego stanowiska zarówno dla sądownictwa kościelnego, jak i dla całego Kościoła katolickiego.

Obrońca węzła małżeńskiego powinien poszerzać swoją wiedzę z dziedziny prawa kanonicznego i nauk społecznych oraz uczestniczyć w organizowanych spotkaniach połączonych $\mathrm{z}$ wymianą doświadczeń ${ }^{30}$. A zatem w osobie pełniącej ten urząd powinny łączyć się zawsze wszechstronna wiedza na temat małżeństwa i odpowiednie doświadczenie duszpasterskie, a także zdolność do całościowej oceny rozpatrywanej sprawy.

\section{Uprawnienia i obowiązki obrońcy węzła małżeńskiego}

Od samego początku, gdy ustanowiono urząd obrońcy węzła małżeńskiego, jego obowiązkiem było przedstawienie i proponowanie wszystkiego, co w sposób rozumny przemawiało przeciw orzeczeniu stwierdzającemu nieważność i rozwiązanie węzła małżeńskiego, lecz zawsze z uwzględnieniem zasady poszanowania prawdy ${ }^{31}$. Dotarcie do prawdy obiektywnej nie oznacza, iż obrońca węzła winien bronić małżeństwa wbrew logice

${ }^{28}$ CiC, can. 1435; por. M. Greszata, Iudicium cum..., dz. cyt., s. 231.

${ }^{29}$ Lex propria sacrae Romanae Rotae et Signaturae Apostolicae, dz. cyt., s. 441, can. $4 \$ 2$ : „[...] debent esse [...] maturae aetatis [...]”; por. S. Biskupski, Obrońca węzła..., dz. cyt., S. 122.

${ }^{30}$ Szerzej na ten temat: R. Biernat, Obrońca węzła małżeńskiego w procesach I Instancji..., dz. cyt., s. 73-74.

${ }^{31}$ CIC, can. 1432: „Ad causas, in quibus agitur de nullitate sacrae o nationis aut de nullitate vel solutione matrimonii, constituatur in dioecesi defensor vinculi, qui officio tenetur proponendi et exponendi omnia quae rationabiliter adduci possint adversus nullitatem vel solutionem"; por. J. Krukowski, Artykuł 3. Promotor sprawiedliwości..., dz. cyt., s. 48. 
i wiarygodnym dowodom ${ }^{32}$. Podobne wymaganie sugerowałoby wysiłek niczemu niesłużący, ponieważ obrona taka byłaby przeciw dochodzeniu do poznania prawdy obiektywnej. Obowiązkiem obrońcy węzła było zawsze czuwanie nad tym, by proces przebiegał zgodnie z przepisami prawa kanonicznego, aby zgromadzono wszelkie dowody dla ukazania prawdy o ważności lub nieważności danego małżeństwa. Miał on zawsze na przestrzeni lat prawo uczestniczyć w przesłuchaniu stron, świadków i biegłych oraz zapoznać się z aktami sądowymi przed ich opublikowaniem. Umożliwiało mu to stałą obecność w kanonicznym procesie małżeńskim, a jednocześnie mobilizowało to go do aktywnego zaangażowania w toczące się postępowanie dotyczące zaskarżonego małżeństwa ${ }^{33}$. Uprawnienia te należy postrzegać jako mające duże znaczenie procesowe. Podkreślają one od początku aktywną funkcję obrońcy węzła w procesach małżeńskich.

Kolejny obowiązek obrońcy węzła - zarówno w prawie wcześniejszym, jak i obecnym - to proponowanie i przedstawianie logicznych argumentów, które racjonalnie broniłyby ważności małżeństwa. Proponować oznacza przytaczać rozumnie argumenty przeciwko rozpadowi małżeństwa i postulować jego ważność. Natomiast przedstawiać oznacza przytaczać zarówno ustawy, jak i normy proceduralne, które można zastosować, oraz fakty wraz z oceną wartości przytoczonych dowodów ${ }^{34}$. Do jego obowiązków należało również przedkładanie sędziemu pytań. Miały być one przygotowane w formie pisemnej i zdeponowane w zamkniętej oraz opieczętowanej kopercie, którą sędzia otwierał dopiero w czasie przesłuchania, a potem przedstawiał je stronom, świadkom lub biegłym, w zależności od tego, do kogo były skierowane. A zatem od samego początku ustanowienia w strukturach kościelnych obrońcy węzła małżeńskiego jego obowiązkiem było odpowiednie ułożenie pytań, tak aby miały one ścisły związek ze sprawą.

${ }^{32}$ Por. Pius XII, Discorso del 02.10.1944, AAS 36 (1944), s. 283.

${ }_{33}$ CIC, can. 1433: „In causis in quibus promotoris iustitiae aut defensoris vinculi praesentia requiritur, iis non citatis, acta irrita sunt, nisi ipsi, etsi non citati, revera interfuerint, aut saltem ante sententiam, actis inspectis, munere suo fungi potuerint”.

${ }^{34}$ Por. C. de Diego-Lora, Artykuł 3. Rzecznik sprawiedliwości, obrońca węzła i notariusz, tłum. R. Kantor, w: Kodeks prawa kanonicznego. Komentarz. Powszechne i partykularne ustawodawstwo Kościoła katolickiego. Podstawowe akty polskiego prawa wyznaniowego, red. P. Majer, Kraków 2011, s. 1074. 
Według Kodeksu prawa kanonicznego z 1917 roku do każdej czynności procesowej, przy której obrońca węzła małżeńskiego miał prawo być obecny, należało go według przepisów prawa wezwać, inaczej czynności te były nieważne. Brak wezwania nie powodował nieważności, jeśli sam faktycznie się stawił na czynności sądowe $\mathrm{w}$ trakcie trwania procesu. $\mathrm{W}$ razie jego nieobecności mimo wezwania przez sędziego miał obowiązek przeanalizować w późniejszym terminie akta sprawy, aby był w stanie na piśmie lub wyjątkowo ustnie przedstawić swoje uwagi ${ }^{35}$. Prawo kanoniczne dawało mu uprawnienie do żądania od sędziego przedłożenia dokumentów, jeśli to uznał za potrzebne ${ }^{36}$, a także do przytaczania tego wszystkiego, co może być do obrony ważności małżeństwa użyteczne ${ }^{37}$. Mógł też prosić sędziego przesłuchującego o postawienie zaproponowanego przez niego pytania, jeśli nasunęło mu się ono w trakcie czynności procesowych, w których brał udział. Dysponował prawem wnioskowania o powołanie jeszcze innych świadków albo o ponowne ich przesłuchanie, nawet po zamknięciu postępowania dowodowego lub ogłoszeniu akt sprawy, oraz przedkładania nowych uwag. Miał też możliwość domagać się, by dalsze czynności procesowe przez niego wskazane zostały przedsięwzięte, chyba że sąd kolegialny jednogłośnie się temu sprzeciwił $3^{38}$. Obrońca węzła miał obowiązek zebrać odpowiednie wiadomości, zwłaszcza od obrońcy węzła tej diecezji, w której małżeństwo zostało zawarte, oraz zażądać od proboszcza, któremu przysługiwało prawo asystowania

35 CIC, can. 1433.

36 Por. F. Bączkowicz, Prawo kanoniczne, dz. cyt., s. 196.

37 СІСв, can. 1968: „Defensoris vinculi est: $1^{\circ}$ Examini partium, testium et peritorum adesse; exhibere iudici interrogatoria clausa et obsignata, in actu examinis a iudice aperienda, et partibus aut testibus proponenda; novas interrogationes, ab examine emergentes, iudici suggerere; $2^{\circ}$ Articulos a partibus propositos perpendere, eisque, quatenus opus sit, contradicere; documenta a partibus exhibita recognoscere; $3^{\circ}$ Animadversiones contra matrimonii nullitatem ac probationes pro validitate aut pro consummatione matrimonii scribere et allegare, eaque omnia deducere, quae ad matrimonium tuendum utilia censuerit"; por. F. Bączkowicz, Prawo kanoniczne, dz. cyt., s. 195-196.

${ }^{8}$ СІсв, can. 1969: „Defensori vinculi ius esto: $1^{\circ}$ Semper et quolibet causae momento acta processus, etsi nondum publicati, invisere; novos terminos ad scripta perficienda flagitare, prudenti iudicis arbitrio prorogandos; $2^{\circ}$ De omnibus probationibus vel allegationibus ita certiorem fieri, ut contradicendi facultate uti possit; $3^{\circ}$ Petere ut alii testes inducantur vel iidem iterum examini subiiciantur, processu etiam absoluto vel publicato, novasque animadversiones edere; $4^{\circ}$ Exigere ut alia acta, quae ipse suggesser it, conficiantur, nisi tribunal unanimi suffragio dissentiat"; por. F. Bączkowicz, Prawo kanoniczne, dz. cyt., s. 196. 
przy ślubie, autentycznego odpisu protokołu badań przedślubnych i pytań postawionych nupturientom ${ }^{39}$.

Na podstawie ustaleń konstytucji apostolskiej papieża Benedykta XIV i późniejszych unormowań wymogiem do orzeczenia nieważności małżeństwa były 2 zgodne wyroki wydane przez różne instancje trybunału kościelnego, a obrońca węzła małżeńskiego był zobowiązany do złożenia apelacji od wyroku pierwszej instancji stwierdzającego nieważność małżeństwa. Posiadał on również uprawnienia do złożenia apelacji do trzeciej instancji, jaką jest Trybunał Roty Rzymskiej, jeśli w sumieniu uważał 2 zgodne wyroki odrębnych instancji za niesprawiedliwe ${ }^{40}$. Mógł on zaskarżać wyroki, które według niego były nieważne, lub wnosić apelacje do wyższej instancji od niesprawiedliwego w jego ocenie wyroku. Obrońca węzła powinien postępować racjonalnie, dlatego nie był on zobowiązany, by w każdej sprawie wnosić apelację od wyroku orzekającego nieważność małżeństwa lub za wszelką cenę w każdej sprawie walczyć w obronie ważności małżeństwa, odrzucając nawet racjonalne działania.

Prawa i obowiązki obrońcy węzła małżeńskiego były i są wystarczającymi narzędziami do obrony instytucji, jaką jest małżeństwo. Dzięki nim skutecznie mógł on - według dawnego prawa kanonicznego i może według prawa obecnie obowiązującego - stać na straży małżeństwa dobra publicznego.

\section{Zakończenie}

Podsumowując refleksję nad historyczno-prawnymi aspektami urzędu obrońcy węzła małżeńskiego w świetle obowiązującego prawa kanonicznego i praktyki sądowej w diecezji tarnowskiej, należy przede wszystkim podkreślić, że jego rola polegała na rozumnym i słusznym podważaniu argumentacji sugerującej nieważność małżeństwa. W tym celu obrońca węzła małżeńskiego zawsze wykorzystywał wszelkie godziwe sposoby, jakie przewidywało prawo kanoniczne. Głównym zadaniem obrońcy węzła było przedstawienie tego wszystkiego, co przemawiało za ważnością węzła małżeńskiego, dlatego powinien był on uczestniczyć we wszystkich sprawach i procesach dotyczących małżeństwa.

\footnotetext{
39 Por. F. Bączkowicz, Prawo kanoniczne, dz. cyt., s. 196.

${ }^{40}$ Por. M. Greszata, Iudicium cum..., dz. cyt., s. 230.
} 
Posługa obrońcy węzła małżeńskiego wymaga znajomości prawa kanonicznego, ale i umiejętności łączenia wiedzy naukowej oraz doświadczenia z konkretnymi sytuacjami ludzkimi. Obrońca węzła to urząd od początku przewidziany dla procesowej obrony, a także ochrony ważności i nietykalności węzła małżeńskiego. Uosabia on zasadę przychylności prawa wobec małżeństwa, jak i troskę Kościoła o nie. Jego istotę stanowi prawo, a zarazem obowiązek wypełniania z powagą i rzetelnością swojej misji w każdym procesie małżeńskim. A zatem niepodważalne jest stwierdzenie, że kroki prawne poczynione przez papieża Benedykta XIV w XVIII wieku dały podwaliny pod rozwój kanonicznego procesu w sprawach o stwierdzenie nieważności małżeństwa. Papież rozpoczął nowy rozdział, powołując do istnienia instytucję obrońcy węzła, co powoli, ale systematycznie polepszyło stan sądownictwa kościelnego, aż wreszcie po dłuższym czasie przywróciło mu należne miejsce i znaczenie. 
